\title{
BUILDING INNOVATION MANAGEMENT ASSESSMENT THEORY FRAMEWORK THROUGH THE LENS OF TQM
}

FU Qiang, Institute of Technical Education, Singapore

dx.doi.org/10.18374/IJBR-20-1.5

\begin{abstract}
Practically, quantifying, evaluating and benchmarking innovation capability or practice is a significant and complex issue for many contemporary organizations. Indeed, there are similarities in what innovation management and TQM trying to achieve. However, Can TQM function as a specific resource that allows organizations to build their competence and capability in innovation? Hence, this researcher for the 1st time examined the innovation management assessment framework developed through the lens of TQM and provided some unique insights as to the synergies between this 2 different stream of theories and their applications in relation to innovation management.
\end{abstract}

Keywords: innovation management, innovation capability, TQM, assessment, company performance 